\title{
Correction to: Multilateral development banking in a fragmented climate finance system: shifting priorities in energy finance at the Asian Development
}

\section{Bank}

\section{Laurence Delina ${ }^{1}$}

\section{Correction to: Int Environ Agreements (2017) 17:73-88} https://doi.org/10.1007/s10784-016-9344-7

The article title was incorrectly published in the original publication. The correct title is given in this correction.

The original article can be found online at https://doi.org/10.1007/s10784-016-9344-7.

Laurence Delina

ldelina@bu.edu

1 Postdoctoral Associate, Frederick S. Pardee Center for the Study of the Longer-Range Future, Boston University, 67 Bay State Road, Boston 02215, MA, USA 